\title{
Leadership in the Service of Hospitality
}

by JUDI BROWNELL

The definition of leadership has changed considerably in the past one hundred years, beginning with the "great man" concept and, more recently, focusing on "transformational leadership." The next step in leadership evolution is servant leadership, in which the leader seeks to support and empower followers. The implications are considerable for the hospitality industry, since it is based on the concept of leadership through service. Hospitality educators could take steps to instill servant leadership principles in students to equip them for this increasingly relevant leadership style.

Keywords: leadership; servant leadership; transformational leadership; hospitality education

Service is the rent each of us pays for living - the very purpose of life and not something you do in your spare time.

-Marion Wright Edelman, president of the Children's Defense Fund, 2004

The history of leadership theory is a fascinating story of evolving views on the nature of human behavior and the ways individuals acquire power and influence in the workplace. Thoughts about how leadership is defined, the characteristics of effective leaders, and accepted leadership philosophies have evolved with every passing decade. The one constant theme, as Drucker (1998) and others have repeatedly emphasized, is that leadership matters. Today's hospitality organizations affect the larger society in which they operate, reflecting the norms and values of the people who work within them.

As the Cornell Hospitality Quarterly looks back on a half century of publication, the changes it has recorded in leadership theory and practice illustrate the evolution of approaches to understanding the relationship between leaders and followers in hospitality organizations. Never before has leadership been a more central concern than in the current decade. Recent events have demonstrated beyond a doubt that not only does leadership matter, but the character of the leader matters. We have vividly witnessed how a leader's actions, values, and ethical standards can affect our global economy and the quality of life for citizens worldwide. Global hospitality organizations, in particular, are profoundly affected by a leader's behaviors and personal characteristics and especially the manner in which the leader relates to and influences followers. 
Given today's business climate and the growing need for leaders who can guide with integrity and courage in the years ahead, it seems appropriate to explore an emerging leadership philosophy that facilitates employee care and environmental stewardship, promotes a culture of trust and respect, and encourages ethical practices in a global hospitality context. The servant leadership perspective, first presented by Robert Greenleaf(1977), shows promise for guiding an industry focused directly on creating service excellence and providing "hospitality."

In this article, I first survey a set of relevant articles on leadership that were published during the past quarter century in the Cornell Hospitality Quarterly and other management journals. These publications highlight the development in management thought regarding how leaders view their role and responsibilities and, subsequently, influence their organization's culture and performance. I then suggest that servant leadership holds particular promise for restoring public trust and employee engagement. This emerging approach to leadership is examined in light of the pressing issues businesses are confronting as we move into the second decade of the twenty-first century-leaders whose motives are often questionable and a workforce that has become increasingly stressed, disillusioned, and disengaged. In the final section of this article, I examine the hospitality curriculum and suggest possible approaches to increasing emphasis on several of the most relevant servant leadership principles and practices.

\section{History of Leadership Theory}

A brief look back in time illustrates how far we have come in our thinking about leadership theory and practice. For instance, a 1920 definition of leadership reads, "the ability to impress the will of the leader on those led and induce obedience, respect, loyalty, and cooperation" (Moore 1927, 124).
Another early author focused on the qualities of effective leaders, proposing that "married men from 30 to 40 years and single women from 25 to 35 have the best chance for leadership success. ... Women ... with average intelligence will succeed if they have other good qualities" (Ho and Macy 1929, 231). As for early leadership philosophies, one author wrote, "We have not reached a condition anything like industrial democracy, and there is no indication that we are headed in that direction which, after all, is rather fortunate. Wage earners are not running the business; they don't want to and they don't know how" (Cowdrick 1930, 32).

We have, indeed, come a long way. Numerous leadership theories have been proposed over the past decades; of these, a few of the most significant are described below. While these perspectives vary on a number of dimensions, our focus is on identifying the key features that distinguish each approach and, ultimately, providing a context for appreciating the principles of servant leadership and its potential contributions to hospitality organizations of the future. Of special note are articles that have appeared in the Cornell Hospitality Quarterly over the past quarter century.

\section{Early Leadership Theories}

Early theories focused almost exclusively on personal characteristics of the leader and attempted to better understand the reason for his or her impact on organizational performance. In fact, one of the first perspectives was called the "great man" theory under the premise that leaders (at that time, almost exclusively male) were born, not made. Similarly, trait theories assumed that certain characteristics and personalities made an individual a better leader and consequently sought to identify those qualities (Mann 1959; Stogdill 1948). After a decade of research, studies by Stogdill and others concluded that no single characteristic 
distinguishes effective leaders from less effective ones. Focus then turned to describing what leaders do.

During the 1950s and 1960s, behavioral theories emerged with increasing frequency. Theorists proposed that individuals could learn to be leaders through skill development and deliberate action. Patterns of behavior were labeled "leadership styles." Blake and Mouton's Managerial Grid (1964), for instance, proposed that leaders could be distinguished by their concern for tasks or concern for people and by their tendency to be either directive or participative in their approach.

\section{The Past Quarter Century of Leadership Theory}

While the earliest theories focused on the leader's characteristics and competencies in search of the key to greater effectiveness, thinking during the past twenty-five years has generally taken a broader view that considers both the dynamics created between the leader and his or her followers as well as the context and features of the particular environment.

Contingency theories consider contextual aspects of leadership effectiveness, recognizing that situational variables are significant in determining the impact and outcomes of various leader behaviors. Those who were flexible and could adapt to different contexts increased their effectiveness. Fiedler (1967) was one of the first to apply a contingency approach using his least-preferred-coworker scale, which assessed the relative importance of relationship, power, and task structure. Hershey and Blanchard's situational leadership model (1988) proposed that four basic leadership styles - telling, selling, participating, and delegating - were more or less effective depending on the needs of the followers and the nature of the situation. Blanchard's work has frequently been applied to hospitality settings $(1991,1992,1995)$.
Other authors such as Cichy, Sciarini, and Patton, writing in the Cornell Quarterly in 1992, sought to identify the leadership behaviors particularly relevant to a particular context-in this case, food-service operations.

\section{Transformational Leadership}

If we examine literature over the past twenty-five years, it could be argued that the style of most relevance to hospitality leaders has been transformational (Bass 2000; Bennis 2002; Tichy and Ulrich 1984; Yammarino, Spangler, and Bass 1993; Avolio and Gardner 2005). First defined by Burns (1978), transformational leadership was readily distinguished from earlier transactional approaches in both focus and behavior. Transformational leaders' effectiveness was often based on their charisma and the strong relationships they established. These leaders developed and maintained collaborative relationships by establishing open communication, forming and supporting team efforts, and providing the necessary resources to fulfill a shared vision (Humphreys and Einstein 2003; Stone, Russell, and Patterson 2004). Repeatedly, researchers found that one of the main differences between successful and derailed leaders was the ability to build and sustain the interpersonal relationships so essential to the transformational leader's effectiveness (Bass and Steidlmeier 1999; Van Velsor and Ascalon 2008). These leaders served as change agents by creating a vision and inspiring followers to work toward common organizational goals. As one author put it, transformational leaders "manage the dream" (Bennis 2000, 46).

The past two decades have witnessed a growing interest in transformational leadership as a key to effectiveness in high-touch hospitality environments. Tracey and Hinkin, for instance, studied the outcomes of transformational leadership in a hotel management 
firm (1994). They also used a sample of lower- and middle-level hotel managers to explore the measurement qualities and practical utility of two leadership assessment instruments including the transformational leadership scales of the Multifactor Leadership Questionnaire (1998). Another research team reported on a project that examined the leadership styles that influence front line hotel employees. Results of that study revealed that the shared values inspired by transformational leaders were among the most important variables for employee motivation and satisfaction (R. A. Clark, Hartline, and Jones 2009; Hermalin 1998).

Looking ahead, I see yet another perspective, servant leadership, emerging as an increasingly relevant theory that shares many transformational leadership principles. While articles on servant leadership have yet to appear in hospitality journals, there is little question that this approach holds promise for service organizations seeking to avoid the unethical and self-serving practices of the past decades and to foster community, trust, and integrity through service. The next section describes the principles of servant leadership theory and illustrates how servant leaders are well positioned to accomplish the most critical and often illusive tasks confronting tomorrow's hospitality leaders.

\section{Movement to Servant Leadership}

Servant leadership captures and reimagines elements from earlier thinking on the requirements of both the individual as leader and his or her relationship with followers. Servant leaders demonstrate the flexibility required for effectiveness in a culturally diverse workplace, incorporating the positive and appropriate aspects of other leadership models. The essence of servant leadership is that the leader is motivated by a desire to serve and empower followers; influence is achieved through the act of service itself. This characteristic is key, and it results in an egalitarian leader-follower relationship as well as a values-based organizational culture. While servant leaders have been associated with religious goals, the principles of servant leadership are particularly relevant to hospitality organizations seeking to distinguish themselves by their employee-centered and ethical practices. Efforts to provide empirical support for the concept and to develop a cohesive theory are increasing as its relevance in today's turbulent times becomes increasingly apparent (Barbuto and Wheeler 2006; Farling, Stone, and Winston 1999; Russell and Stone 2002).

An individual's integrity, character, and personal values are key in determining his or her effectiveness as a servant leader (Giampetro-Meyer et al. 1998; Griffith 2007; Liden et al. 2008). Servant leaders engage in continuous self-reflection, examining their personal belief systems so that their actions will be consistent with espoused values (Ciulla 1995; May et al. 2003; Simons 2002; Washington, Sutton, and Field 2006). Such self-reflection is critical, as a leader's values affect his or her ethical decision making; they influence choices and shape subsequent interpretations of events (Russell 2001). Values also serve as a guide in problem solving, conflict resolution, and other activities that directly impact the organization and its members (Kouzes and Posner 1995; Malphurs 1996).

The distinguishing principles of servant leadership can best be described as they are compared and contrasted with the emphasis and features of transformational leadership theory. In a recent article, Parolini, Patterson, and Winston (2009) reported on a study that revealed statistically significant differences between transformational leaders and servant leaders on the following five dimensions: ethics, focus, motive and mission, development, and means of influence. Russell (2001) proposes that the leader's values may 
be the strongest underlying factor that separates servant leaders from transformational and other leadership styles. For example, transformational leaders are focused on the needs and goals of the organization, while a servant leader's primary focus is on developing his or her followers as an end in itself (Ehrhart 2004). While transformational leaders create "empowered dynamic" cultures (Msith, Montagno, and Kuzmenko 2004), servant leaders' motivation to serve and empower employees results in more stable, evolutionary internal environments. Other researchers (Graham 1991; Humphreys 2005; Smith, Montagno, and Kuzmenko 2004; Stone, Russell, and Patterson 2004) have come to similar conclusions regarding distinctions in focus and outcomes between these two approaches.

The roots of the servant leader philosophy can be found in a number of Quarterly articles throughout the past quarter century. Perhaps the first clear example of this perspective was presented by Walker in 1986 when he proposed that hospitality professionals must have the integrity and courage to serve and support their employees (p. 14). Sternberg (1992) argued for hospitality leaders to move from control to trust and joined those who highlighted the importance of an empowered workforce to meet challenges in the years ahead.

Herman and Cullen, in another 1986 Quarterly article, called for individuals with a strong sense of ethics to lead in a world scarred by questionable business practices, noting,

The evidence of ethical lapses has been particularly strong in recent months. We have read about insider trading on Wall Street, the sale of government secrets to foreign powers, and of an airline that advertises low prices but collects high fees for services en route. . . . It is no wonder that, according to a recent Gallup poll, 63 percent of Americans are dissatisfied with the country's ethical standards. (P. 49)
J. J. Clark and Arbel (1993) likewise foreshadowed the need for global leaders who had "the courage to make and stand by the right decisions in spite of . . constraints." A more recent $C Q$ article concluded, "The main path of leadership influence lies in increasing the extent of shared values between the organization and its employees" (R. A. Clark, Hartline, and Jones 2009, 224). They emphasized the importance of the leader's personal commitment to facilitating outcomes consistent with both personal and organizational values.

Clearly, servant leaders are distinguished by how they behave. In his discussion of Greenleaf's servant leader, Spears (1998a) identifies several defining activities, among them listening well, practicing stewardship, and demonstrating a strong commitment not only to human development but also to the building of community (Exhibit 1). Nearly every one of the attributes of servant leadership has been subsequently addressed by researchers interested in exploring the link between leadership effectiveness and servant leader behaviors (e.g., D. M. Mayer, Bardes, and Piccolo 2008; Rennaker 2008; Russell \& Stone 2002).

Assessment instruments have also provided support for a number of characteristics shared by servant leaders. Laub's (2003) Organizational Leadership Assessment focuses on such dimensions as a leader's authenticity, ability to build community, and empower employees. An instrument has also been developed to further examine Patterson's (2003) seven-component theory of servant leadership. This survey assesses humility, trust, and empowerment, among other factors (Dennis and Bocarnea 2005). Yet another survey, the Servant Leadership Questionnaire, has produced five servant leadership factors that include organizational stewardship (Barbuto and Wheeler 2006). Similarly, the Servant Leadership 


\section{Exhibit 1:}

Behaviors Associated with Servant Leaders

1. Listening intently to others combined with personal reflection on what is heard

2. Empathy: assuming the good intentions of colleagues

3. Awareness: understanding issues involving ethics and values

4. Persuasion, rather than relying on authority or coercion

5. Conceptualization: servant leaders dream great dreams and are also operationally skilled

6. Foresight: the ability to foresee the likely outcome of a situation

7. Stewardship: holding institutions in trust for the greater good of society

8. Commitment to the personal and professional growth of all employees

9. Building community within the organization

Source: Adapted from Spears (1998a, 1-5).

Behaviour Scale is a measure of six dimensions, including service orientation and an emphasis on ethical practices (Sendjaya, Sarros, and Santoro 2008). Recently, Liden and his colleagues (2008) developed a seven-factor model that provides additional support for the widely held belief that servant leadership is a multidimensional construct, sharing many characteristics of transformational leaders while maintaining a distinct focus on service, personal integrity, and ethical practices.

In the next section I discuss why servant leadership is a particularly relevant theory for hospitality leaders seeking to create strong service environments in today's workplace. Two of the most relevant and powerful outcomes - developing a culture of trust and respect and fostering ethical practices in a global workplace - are examined in more detail as they illustrate how the characteristics of servant leaders are well suited to guide today's service organizations into the future.

\section{Servant Leaders Well Positioned to Address Key Challenges}

One of the key questions throughout the history of leadership theory has been, How should leaders treat followers? For servant leaders, the answer is clear; the servant leader philosophy is directly aligned with the mission of hospitality organizations. Consistent with E. M. Statler's statement that "life is service. The one who progresses is the one who gives his fellow human beings a little more, a little better service," servant leaders practice leadership as hospitality (Bennett 2007). The assumption, "I am a leader, therefore I serve," is embedded in the concept of house manager, one to whom something of great value is entrusted (Sendjaya and Sarros 2002; Senge 1990). The servant leader sees his or her role as steward of the organization and custodian of its standards (Block 1993; Russell 2001).

As definitions of customer service turn to customer care, servant leadership becomes increasingly relevant. Servant leaders appreciate, encourage, and care for their followers (Russell 2001; Schueler 2000). Employees, inspired by the example their leader sets, in turn provide generous and genuine care to guests. When employees take personal responsibility for addressing each guest's needs, when they serve out of a personal commitment to provide value and assistance, service becomes authentic and quality increases. This customization of service translates into high customer satisfaction and subsequent organizational effectiveness (Autry 2004; Covey 2006; Spears 1996).

A servant leader's scope of concern extends beyond the organization and into the larger social and physical environment. These individuals feel a profound responsibility to participate in and contribute to the 
larger society (Barbuto and Wheeler 2006). As Blanchard (1997) pointed out well over a decade ago, servant leaders extend their reach to all of their various stakeholders and the communities to which they belong (Banutu-Gomez 2004). As sustainability becomes an increasingly critical topic for global hospitality organizations, servant leaders' philosophy of stewardship ensures their commitment to protect the environment as well. While "green" efforts have increased substantially over the past decade, many ecological initiatives have been undertaken as a response to public pressure or regulatory compliance rather than as the result of a sincere belief in the importance of environmental protection (Sharma 2000; Fineman 1996).

While a servant leadership philosophy has the potential to benefit hospitality organizations in a wide variety of ways, I limit the following discussion to two outcomes that are most relevant for today's troublesome times and that best distinguish the servant leadership philosophy - namely, an empowered workforce characterized by trust and respect and the personal integrity that leads to ethical practices in a values-based organizational culture. These two topics are briefly discussed in light of how a servant leadership approach facilitates each outcome.

\section{Empowerment, Trust, and Respect}

Trust is a multidimensional construct, often defined as the level of confidence an individual has in another's competence and expectations regarding the likelihood that he or she will act in a fair and ethical manner (Dirks and Ferrin 2002; Lowe 1998; R. C. Mayer, Davis, and Schoorman 1995; Shockley-Zalabak, Ellis, and Winograd 2000). Organizational trust does not emerge automatically but grows out of an environment characterized by employee empowerment and shared values. As we have emphasized, the servant leader philosophy holds that leaders are accountable to those they serve rather than vice versa. Few practices are as important to facilitating excellent service as empowerment, which encourages every employee to take personal responsibility for his or her decisions and actions (Russell and Stone 2002).

Empowerment changes not only employees' rights and responsibilities but those of the leader as well (Dennis and Bocarnea 2005; Honold 1997). It requires that leaders put their trust in their staff and respect their judgment (Sternberg 1992; Washington, Sutton, and Field 2006). While I have noted that a number of Cornell Quarterly articles suggest the importance of employee empowerment (for example, Tracey and Hinkin 1994; R. A. Clark, Hartline, and Jones 2009; Sternberg 1992), the servant leader views employees as responsible organizational citizens and then focuses on supporting and responding to the needs they identify (Blanchard 1995; Graham 1995). The trust servant leaders place in their employees allows them to take initiative on their jobs and thereby contributes to greater productivity. It also inspires employees to become "exemplary followers" who are more likely to demonstrate empathy and concern both for their colleagues and their guests (BanutuGomez 2004). Numerous researchers have recognized that the trust resulting from servant leadership practices encourages organizational citizenship behavior and "reclaims the ethos of community" so central to a productive workplace (Ehrhart 2004, 62).

Integrity, as Covey (1989) notes, is one of the most essential characteristics of effective leaders. Numerous scholars agree, naming the key values of truthfulness, fairness, promise keeping, and respectful behavior as among the values that promote a culture of trust (Clawson 1999; Lewis 1996; Russell 2001). Simons's work on behavioral integrity provides further support for the notion that trusted leaders align words and actions. 
When employees perceive their leader as trustworthy - when they keep their promises and act on espoused values - employee commitment, effort, and efficiency increase (Simons 2008). In a study applying Laub's Organizational Leadership Assessment (2003) combined with Nyhan and Marlowe's Organizational Trust Inventory (1997), Joseph and Winston (2005) found that perceptions of servant leadership correlated positively with both leader and organizational trust.

In his best-selling book, Good to Great, Collins (2001) argues that enduring greatness can be achieved only through a blend of personal humility and professional will. Those who study servant leaders emphasize that this orientation does not translate to being "soft"; effectiveness requires inner strength and toughness (Autry 2004). Covey (2006) notes that the greatest test of leadership, and the key to building a healthy organizational culture, is how leaders treat those who test them the most. Abshire (2007) proposes that servant leaders are perceived as trustworthy because they speak up and "tell it like it is," often in difficult circumstances. Servant leaders require a great deal of courage as they strive to balance responsibilities to self, to the organization, and to their various internal and external constituencies (Hamilton 2005; Novicevic et al. 2005; Reinke 2004). McClellan (2007), in fact, found that servant leadership is positively and significantly correlated with psychological hardiness. As stewards of the organization, servant leaders maintain standards and keep everyone focused on achieving excellence.

\section{Ethical Practices in a Global Hospitality Industry}

Patterson $(2003,3)$ described the servant leader as "doing the right thing, at the right time, for the right reasons." Over the past quarter century, too little has been written on leadership ethics in hospitality (Brownell and Stevens 2008; Griffith 2007; Hall 1990, 2009; Ciulla 1999). Perhaps this is because, as Herman and Cullen (1986) noted in the Cornell Quarterly nearly three decades ago, discussing and fostering ethics is like "nailing jello to a wall" (Lewis 1996, 52).

Few theories address how leaders influence judgments about ethical practices more directly than servant leadership (Honold 1997; Hughes, Ginnett, and Curphy 1993). Ethical leadership is noncoercive (Kimbrough 2007; Rost 1995); servant leaders inspire courage to act on ethical principles, even under difficult circumstances (Spears 1998b). Barnard (1958) was among the first to recognize that leaders create ethical codes as they address the organization's central issues. He argued that the leaders' personal ethical orientation influences their decision making, which, in turn, affects the organization's culture and ethical climate (Novicevic et al. 2005). In 1988, Cohen and Neilsen described the internal political environment in which they believed too many hospitality managers were operating:

\footnotetext{
Managers attempted to create obligatory, frequently political relationships with more powerful colleagues. The less powerful manager expressed subordination, loyalty, unsolicited support, and political alignment. In return, the more powerful manager was expected to sponsor this person for future promotion and advancement. (P. 37)
}

Similarly, Van Velsor and Ascalon (2008) warned of temptations that arise as leaders gain access to privileged information from which they might personally benefit. The ability to control organizational resources also has its own ethical risks. Without selfreflection and a strong sense of ethical responsibility, it becomes easy for a leader to inflate his or her personal abilities and sense of entitlement, potentially leading to unethical consequences. 
While both servant and transformational leaders seek to empower employees, servant leadership adds an ethical emphasis beyond what is generally found in transformational leadership theory. Arguments have been posed that transformational leaders, highly motivated to accomplish their organizational goals, may be tempted to use their charisma and misrepresent aspects of the situation to their followers (Graham 1991). Followers, in turn, caught up in a compelling vision, may not recognize a leader's ulterior motives or poor ethical standards (Conger 1990; Conger and Kanungo 1987; Sankowsky 1995). Servant leaders, on the other hand, influence through reciprocity. When acting in the best interest of others, a positive form of reciprocation is encouraged whereby followers respond not by serving the leader, but by serving others. Servant leaders trust their employees to undertake actions that are in the best interest of the organization, believing that the organization's goals can be realized on a long-term basis only by facilitating employee development and well-being (Stone, Russell, and Patterson 2004).

There will, no doubt, be increasing ethical dilemmas as the expansion of hospitality operations into foreign nations continues. Globalization requires, as Herman and Cullen (1986) pointed out, not so much coming up with the right answers as asking the right questions. Leaders, J. J. Clark and Arbel (1993) suggested in the Quarterly several years later, must consider the impact of decisions not just locally but on the global community and environment. They recognized the need for leaders to display courage in making, and standing by, decisions that were in the best interests of long-term survival and sustainability. It has also become all too clear that there is a dangerous shortage of global leaders: men and women who demonstrate integrity and cultural sensitivity, who have a clear vision of global opportunities, and who can mobilize a world-class team to meet these new challenges (ThalerCarter 2000). Numerous scholars and practitioners suggest that there is a shortage of leaders who are committed to the highest ethical practices and who lead by both vision and integrity. This situation can be addressed, in part, by hospitality educators.

\section{Fostering Servant Leadership: The Role of Hospitality Education}

The nature of both work and the workplace has changed dramatically in the past twenty-five years. Repeatedly, studies of hospitality executives report that ethical behavior is critical; integrity repeatedly tops the list of key attributes for effective hospitality professionals (Brownell 2007; Calvert et al. 2008; Chung-Herrera, Enz, and Lankau 2003). Yet the challenges of maintaining integrity and ethical standards increase as the workplace becomes more diverse and as the rapid pace of social and technological change create ever more stressful and impersonal environments. Adequately preparing hospitality leaders to navigate in this uncertain climate would seem to call for a rethinking of leadership education. When the needs of tomorrow's leaders are considered, servant leadership philosophy emerges as one approach that has the potential to enhance the future of both future hospitality leaders and the industry they serve (Billett 2006; Wong and Davey 2007).

The question becomes, Can outcomes like a service attitude, personal integrity, and ethical practices be fostered in management education? Ken Blanchard is among those who have no doubt that the principles of servant leadership can be taught and, most important, can be learned (Blanchard 2007; Grothaus 2004). There is growing evidence that others agree. From seminars on integrating ethics into the business curriculum offered by the Association to Advance 


\section{Exhibit 2:}

The Role of Hospitality Education in Fostering Servant Leaders

The Role of Hospitality Education in Fostering Servant Leaders

Assess Applicants Through Admissions Activities

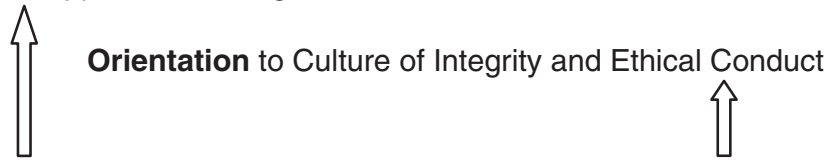

Fostering Servant Leader Principles \& Practices

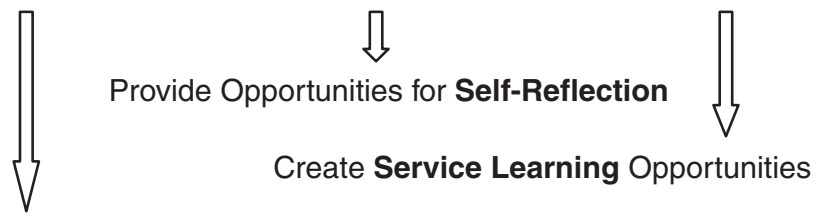

Encourage Role Modeling by all Members of the Academic Community

Collegiate Schools of Business (AACSB) to Greenleaf's Center for Servant-Leadership to the research and training sponsored by the Global Leadership and Organizational Behavior Effectiveness (GLOBE) research consortium, efforts are under way to better understand principles related to servant leadership and how they can be applied to increase individual and organizational health.

The methods used to foster these attitudes and behaviors are less readily apparent. There are, however, several actions that can be taken to communicate a program's commitment to such values as personal responsibility, integrity, and ethical conduct (Exhibit 2).

\section{Use the Admissions Process to Assess Applicants and Orient New Students}

The essence of character is how people think about and treat others. If organizations build their workforce by hiring people of character, coaching them, and then valuing the importance of integrity and citizenship behavior, it would seem that educational institutions might do the same. A strong character and high ethical standards are accessible to everyone. The search for students who take personal responsibility for their actions and who demonstrate a strong commitment to serve can be ascertained by asking the right questions and listening mindfully to the answers. At both the graduate and undergraduate levels, business programs are looking for students who exhibit high ethical standards and respect for others. As Harvard Business School's (2010) description reads, "The right candidates must be eager to share their experiences, support their colleagues, and teach as well as learn from their peers."

\section{Provide Opportunities for Self-Reflection}

Once applicants are admitted, educators must share responsibility for helping future 
industry leaders build character and behave ethically by focusing not only on what students learn but also on who they become as members of a global community. Students who understand that they are defined by the choices they make, day in and day out, will be better prepared to align values and behavior as they step into hospitality leadership roles.

The foundation for building character is self-awareness, which begins by asking students to identify the personal beliefs and values that underpin their behavior, those things on which they are not prepared to compromise (Stewart 2005). This is particularly insightful when students come from different cultures and hold different assumptions. While skeptics question whether business schools really help students take a hard look at who they are and why they are interested in leading, those who support values education remind us that effective leadership starts on the inside. To instill trust, leaders must first exhibit the personal conviction and authenticity that comes from self-knowledge (Blanchard 2007; Simons 2002, 2008).

Yet the troubling fact is that undergraduate business students appear to demonstrate more frequent unethical acts than their counterparts in other programs (McCabe, Butterfield, and Treviño 2001). One theory to explain this observation is that the students are learning something in business school that leads them to adopt these attitudes (Ghoshal 2005; McCabe, Butterfield, and Treviño 2006). A study conducted by the Aspen Institute (2003) found that, during their time in an MBA program, students' values shifted away from customer needs and product quality and toward shareholder value as a measure of corporate responsibility. Faculty interested in fostering a service attitude need to become mindful of the direct and indirect ways in which students' perceptions of appropriate business practices are shaped.

\section{Incorporate Service Learning into the Hospitality Curriculum}

Hospitality industry executives have repeatedly emphasized the importance of developing social consciousness and a sense of responsibility for environmental stewardship (Yeung 2004). Given that successful hospitality students are often focused on achieving their own professional goals, can educators foster a servant leader philosophy? Jeremy Brandt, founder of FastHomeOffers. com, is one of many who believe that volunteer work might be part of the answer (Buchanan 2007). A natural outgrowth of servant leadership has been the increasing interest in service learning (Koppel, Kavanaugh, and Van Dyke 2004; Marshall 2008; Spears 1996). In fact, the National Society for Experiential Education has adopted service learning as one of its major program areas.

Business educators today are addressing the distinct characteristics of the millennials (those born late in the twentieth century), helping them to recognize that it is not "all about me" but about personal responsibility and their ability to help others (Keith 2009). Most millennials recognize their social responsibility. Blair Sheppard, dean of Duke University's Fuqua School of Business, noted in an interview with McKinsey Quarterly editor Allen Webb that today's students want to leave "some trace on the world that matters" (2010). To foster servant leadership practices, Sheppard suggested that second-year students assume responsibility for enhancing the competencies of first-year students. This simple model has application for hospitality programs. Creative approaches to service learning can expand students' perspectives as they reinforce the importance of a service orientation for future hospitality leaders. 


\section{Recognize Applications of Servant Leadership to Teaching and Learning}

Hays (2008) argues that applying the principles of servant leadership to management education can make a profound difference in the impact of the learning experience on both students and educators. He compares and contrasts traditional educational paradigms with the servant leadership model, believing that a servant leader approach results in such outcomes as greater intellectual challenge and engagement, increased autonomy and self-direction, greater sensitivity to diversity, and better transfer of learning outside the classroom.

Several of the best practices suggested for businesses seeking to cultivate servant leadership characteristics apply to academic environments. A summary by Wong and Davey (2007) proposes the following:

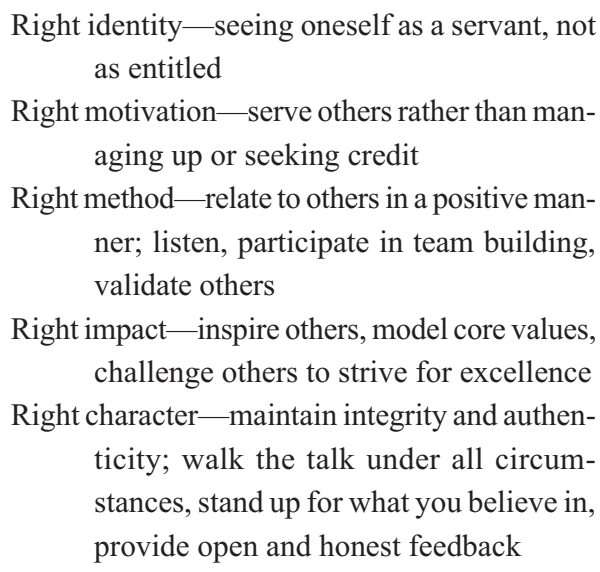

The path to servant leadership is not always direct, and students must be encouraged to cultivate a long-term view of the journey. Educators can help each student to see the value in doing what is right, even if it is not immediately recognized or rewarded. One author compared this potential frustration to a chapter in Winnie the Pooh when Rabbit lamented, "There are days when spelling Tuesday simply doesn't count"
(Stewart 2005, 3). For hospitality leaders, spelling Tuesday always counts.

While focus is on facilitating these outcomes in student learners, faculty may find that modeling servant leader attitudes and practices can help them to facilitate personal responsibility and high standards of ethical behavior. When faculty demonstrate empowerment and build trust, they can raise students' expectations regarding the requirements of their future hospitality leadership role (Caldwell and Jeane 2007; Hays 2008). When the business world is plagued with ethical dilemmas and self-serving practices, a new leadership emphasis in our classrooms may be what is needed for our graduates to create a new hospitality workplace when they move out into the field.

\section{Companies Apply Servant Leadership Practices}

Servant leadership approaches have been implemented in some of the best companies in America and, many would argue, have fostered openness, inclusiveness, fairness, and pride (Levering and Moskowitz 2000; Sendjaya and Sarros 2002). Koch (2004) is among those who believe servant leadership enabled Southwest Airlines to be the only airline to thrive after the terrorist attacks on NYC's twin towers in 2001. Spears (2004) identifies a number of companies that have adopted servant leadership principles in their corporate philosophies. These include Toro Company (Minneapolis, MN), ServiceMaster (Illinois), the Men's Wearhouse (Fremont, CA), and TD Industries (Dallas, TX). One of the earliest practitioners of servant leadership, TD Industries has consistently ranked in the top one hundred of Fortune's best companies to work for in America.

If we look to applications in hospitality and health care, we find that Ari Weinzweig and Paul Saginaw, cofounders of Zingerman's Community of Businesses, built their food, 
restaurant, and training company on servant leadership principles. Employees are asked to take responsibility for their own training and are invited to attend management meetings. The company gives their employees the trust and autonomy to do whatever they believe is necessary to satisfy customers. Turnover is half the national average (Buchanan 2007). Eliot Swartz, cofounder of Two Chefs on a Roll, a private-label food manufacturer in Carson, California, discovered the power of servant leadership by working in an emergency room and then applied these principles to food service. A study of servant leadership conducted at the Culinary Institute of America found no significant correlations between gender, age, or locus of control on students' servant leader behavior (Bartholomew 2006).

The North Mississippi Medical Center, recipient of the 2006 Malcolm Baldrige National Quality Award in the health care category, attributed its effectiveness to the practice of servant leadership (Goonan 2007). The award criteria embrace the personal involvement of leaders and the role of the organization in fulfilling responsibilities to the public, including leading and contributing as a corporate citizen within the larger community (Dering 1998).

Companies large and small are discovering that the principles and practices of servant leadership can bring a renewed sense of community and focus to organizations. While not a theory for all times or all contexts, servant leadership nevertheless has the potential to restore lost faith in leaders, help organizations build trust and community, and demonstrate that it takes more than just the bottom line to make a hotel or restaurant successful.

\section{Conclusion}

Leaders make a difference; their behavior has an enduring consequence beyond its impact on the specific organization, what
Coleman (1998) and others have called "legacy leadership." Servant leaders have the potential to address the hospitality industry's most pressing concerns as the business world struggles to find a path toward integrity and ethical conduct in the wake of abuses and corrupt practices. If today's educators do not take responsibility for helping to shape tomorrow's hospitality leaders, who will? As reflected in Cornell Hospitality Quarterly and other management literature, the development of leadership theory has come a long way over the past several decades - and we cannot afford to stop now.

\section{References}

Abshire, D. 2007. Trustworthy leaders. Leadership Excellence 24 (4): 20-21.

Autry, J. A. 2004. The servant leader: How to build a creative team, develop great morale, and improve bottom-line performance. New York: Three Rivers Press.

Avolio, B., and W. L. Gardner. 2005. Authentic leadership development: Getting to the root of positive forms of leadership. Leadership Quarterly 16 (3): 315-38.

Banutu-Gomez, M. 2004. Great leaders teach exemplary followership and serve as servant leaders. Journal of American Academy of Business, Cambridge 4 (1/2): $143-61$.

Barbuto, J. E., Jr., and D. W. Wheeler. 2006. Scale development and construct clarification of servant leadership. Group \& Organization Management 31 (3): 300-326.

Barnard, C. 1958. Elementary conditions of business morals. California Management Review 1 (1): 1-13.

Bartholomew, S. C. 2006. The influence of gender, age, and locus of control on servant leader behavior among group leaders at the Culinary Institute of America. Ph.D. diss., Walden University, Baltimore. AAT 3219700.

Bass, B. 2000. The future of leadership in learning organizations. Journal of Leadership Studies 7 (3): 18-40.

Bass, B., and P. Steidlmeier. 1999. Ethics, character, and authentic transformational leadership behavior. Leadership Quarterly 10:181-217.

Bennett, J. B. 2007. Engaged, but not heroic, academic leadership. Academic Leadership: The Online Journal 2 (4). http://www.academicleadership.org/leader_action tips/Engaged_But_Not_Heroic_Academic_Leader ship.shtml (accessed August 16, 2009).

Bennis, W. 2000. Managing the dream: Reflections on leadership and change. New York: Perseus Books.

Bennis, W. 2002. Become a tomorrow leader. In Focus on leadership: Servant leadership for the 21st century, ed. L. C. Spears, 101-9. New York: Wiley.

Billett, S. 2006. Work, change, and workers. Dordrecht, the Netherlands: Springer.

Blake, R. R., and J. S. Mouton. 1964. The managerial grid. Houston, TX: Gulf. 
Blanchard, K. 1991. Servant leadership: Today's successful managers are more like cheerleaders than critics. Appleseed.org, http://www.appleseeds.org/Blanchard Serv-Lead.htm (accessed February 4, 2010).

Blanchard, K. 1992. Servant leadership. Executive Excellence 9 (4): 16.

Blanchard, K. 1995. Servant leadership. Executive Excellence 12 (10): 12-13.

Blanchard, K. 1997. Why we can-and should-teach leadership. Forbes.com (accessed October 5, 2007).

Blanchard, K. 2007. Why we can - and should - teach leadership. Forbes.com, http://www.forbes.com/2007/10/05/ executive-mba-teaching-lead-cx kb 1005blanchard .htm (accessed February 4, 2009).

Block, P. 1993. Stewardship: Choosing service over selfinterest. San Francisco: Berrett-Koehler.

Brownell, J. 2007. Meeting the competency needs of global leaders: A partnership approach. Human Resources Management 45 (3): 309-36.

Brownell, J., and B. Stevens. 2008. Communicating standards and influencing behavior: Attending to ethics in the hospitality industry. In Global cases in the hospitality industry, ed. Vinnie Jauhari. New York: Harworth.

Buchanan, L. 2007. In praise of selflessness: Why the best leaders are servants. Inc. Magazine 29 (5): 33-35.

Burns, J. M. 1978. Leadership. New York: Harper \& Row.

Caldwell, C., and L. Jeane. 2007. Ethical leadership and building trust-Raising the bar for business. Journal of Academic Ethics 5 (1): 1-4.

Calvert, C. L., L. Martin, J. Beck, and S. Y. Li. 2008. Identifying unethical academic behaviors of students studying food service, hospitality, tourism and culinary arts. Journal of Culinary Science \& Technology 6 (1): 30-40.

Chung-Herrera, B., C. A. Enz, and M. Lankau. 2003. Grooming future hospitality leaders: A competencies model. Cornell Hotel and Restaurant Administration Quarterly 44 (3): 17-20.

Cichy, R. F., M. P. Sciarini, and M. E. Patton. 1992. Foodservice leadership: Could Attila run a restaurant? Cornell Hotel and Restaurant Administration Quarterly 33 (1): 46-55

Ciulla, J. B. 1995. Leadership ethics: Mapping the territory. Business Ethics Quarterly 5 (1): 5-28.

Ciulla, J. B. 1999. The importance of leadership in shaping business values. Long Range Planning 32 (2): 166-72.

Clark, J. J., and A. Arbel. 1993. Producing global managers The need for a new academic paradigm. Cornell Hotel and Restaurant Administration Quarterly 34 (4): 83-89.

Clark, R. A., M. D. Hartline, and K. C. Jones. 2009. The effects of leadership style on hotel employees' commitment to service quality. Cornell Hotel and Restaurant Administration Quarterly 50 (2): 209-31.

Clawson, J. 1999. Level three leadership: Getting below the surface. Upper Saddle River, NJ: Prentice Hall.

Cohen, H., and E. H. Neilsen. 1988. Finding and developing tomorrow's top managers. Cornell Hotel and Restaurant Administration Quarterly 29 (1): 34-41.

Coleman, A. 1998. Legacy leadership: Stewardship and courage. Health Progress 42 (December): 28-30

Collins, J. C. 2001. Good to great: Why some companies make the leap . . . and others don't. New York: HarperCollins.
Conger, J. A. 1990. The dark side of leadership. Organizational Dynamics 19 (2): 44-55.

Conger, J., and R. Kanungo. 1987. Toward a behavioral theory of charismatic leadership in organizational settings. Academy of Management Review 12 (2): 637-47.

Covey, S. 1989. The 7 habits of highly effective people. New York: Franklin Covey.

Covey, S. R. 2006. Servant leadership. Leadership Excellence 23 (12): 5-6.

Cowdrick, E. S. 1930. Putting workers' ideas to work. Nation's Business 18 (2): 32-35.

Dennis, R. S., and M. Bocarnea. 2005. Development of the servant leadership instrument. Leadership \& Organization Development Journal 26 (7/8): 600-615.

Dering, N. Z. 1998. Leadership in quality organizations. Journal for Quality and Participation 21 (1): 32-35.

Dirks, K. T., and D. L. Ferrin. 2002. Trust in leadership: Meta-analytic findings and implications for research and practice. Journal of Applied Psychology 87 (4): 611-28.

Drucker, P. F. 1998. Management's new paradigms. Forbes 162 (7): 152-69.

Ehrhart, M. G. 2004. Leadership and procedural justice climate as antecedents of unit-level organizational citizenship behavior. Personnel Psychology 57 (1): 61-94.

Farling, M., A. G. Stone, and B. Winston. 1999. Servant leadership: Setting the stage for empirical research. Journal of Leadership Studies 6 (2): 49-72.

Fiedler, F. E. 1967. A theory of leadership effectiveness. New York: McGraw-Hill.

Fineman, S. 1996. Emotional subtexts in corporate greening. Organization Studies 17 (3): 479-500.

Ghoshal, S. 2005. Bad management theories are destroying good management practices. Academy of Management Learning \& Education 4 (1): 75-91.

Giampetro-Meyer, A., Brown, T., Browne, S., \& Kubasek, N. (1998). Do we really want more leaders in business? Journal of Business Ethics, 17(15), 1728-1737.

Goonan, K. J. 2007. Caring culture and results focus lead to Baldrige Award. Quality Progress 40 (3): 41-48.

Graham, J. W. 1991. Servant-leadership in organizations: Inspirational and moral. Leadership Quarterly 2 (2): 105-19.

Graham, J. W. 1995. Leadership, moral development, and citizenship behavior. Business Ethics Quarterly 5 (1): 43-54.

Greenleaf, R. K. 1977. Servant leadership: A journey into the nature of legitimate power and greatness. New York Paulist Press.

Griffith, S. D. 2007. Servant leadership, ethics, and the domains of leadership. Presented at Servant Leadership Research Roundtable, Regent University, School of Global Leadership \& Entrepreneurship, Virginia Beach, VA, July.

Grothaus, T. 2004. Empowering adolescents as servantleaders: Promoting resiliency, positive networking, and community stewardship. Reclaiming Children and Youth 12:228-31.

Hall, S. S. J. 1990. Quality assurance in the hospitality industry. Milwaukee, WI: ASQC Quality Press.

Hall, S. (2009). Journey to Excellence, unpublished manuscript.

Hamilton, F. 2005. Practicing servant-leadership: Succeeding through trust, bravery, and forgiveness. Academy of Management Review 30 (4): 875-77. 
Harvard Business School. 2010. Admissions criteria. http:// www.hbs.edu/admissions/admissioncriteria.html

Hays, J. M. 2008. Teacher as servant applications of Greenleaf's servant leadership in higher education. Journal of Global Business Issues 2 (1): 113-34

Hermalin, B. E. 1998. Toward an economic theory of leadership: Leading by example. American Economic Review 88 (5): 1188-1206

Herman, F. A., and T. P. Cullen. 1986. Still needed: Ethics in business instruction. Cornell Hotel and Restaurant Administration Quarterly 27 (2): 49-52.

Hersey, P., and K. H. Blanchard. 1988. Management and organizational behavior. Englewood Cliffs, NJ: Prentice Hall

Ho, C. J., and R. H. Macy. 1929. Personnel studies of section managers in a department store. Personnel Journal 8 (4): 225-231.

Honold, L. 1997. A review of the literature on employee empowerment. Empowerment in Organizations 5 (4): 202-12.

Hughes, R., R. C. Ginnett, and G. J. Curphy. 1993. Leadership: Enhancing the lessons of experience. New York: Richard D. Irwin.

Humphreys, J. H. 2005. Contextual implications for transformational and servant leadership: A historical investigation. Management Decision 43 (10): 1410-31.

Humphreys, J. H., and W. O. Einstein. 2003. Nothing new under the sun: Transformational leadership from a historical perspective. Management Decision 41 (1/2): 85-95.

Joseph, E. E., and B. E. Winston. 2005. A correlation of servant leadership, leader trust, and organizational trust. Leadership \& Organization Development Journal 26 $(1 / 2): 6-22$.

Keith, K. M. 2009. Servant leaders. Leadership Excellence 26 (5): 18-19.

Kimbrough, L. C. 2007. Perceptions of leader ethical behavior and its relationship to organizational effectiveness: An exploratory study. Dissertation, Capella University, Minneapolis, MN. AAT 3266266.

Koch, C. 2004. Servant leadership. America 191 (1): 17-19.

Koppel, J., R. Kavanaugh, and T. Van Dyke. 2004. Hospitality with a heart: Concepts and models in service-learning in lodging, foodservice, and tourism. Sterling, VA: Stylus.

Kouzes, James M., and Barry Z. Posner. 1995. The leadership challenge: How to keep getting extraordinary things done in organizations. San Francisco: Jossey-Bass.

Laub, J. 2003. From paternalism to the servant organization: Expanding the organizational leadership assessment (OLA) model. Paper presented at the Servant Leadership Roundtable at Regent University, Virginia Beach, VA, October 16

Levering, R., and M. Moskowitz. 2000. The 100 best companies to work for in America. Fortune 141 (1): 82-110.

Lewis, K. M. 1996. Do individual values matter? The effect of team member moral character on work team reputation and performance in a cross cultural setting. Dissertation, University of California, Irvine. AAT 9709933.

Liden, R. C., S. J. Wayne, H. Zhao, and D. Henderson. 2008. Servant leadership: Development of a multidimensional measure and multi-level assessment. Leadership Quarterly 19 (2): 161-77.

Lowe, J. 1998. Trust: The invaluable asset. In Insights on leadership: Service, stewardship, spirit, and servant-leadership, ed. L. C. Spears, 68-76. New York: Wiley.

Malphurs, A. 1996. Values-driven leadership: Discovering and developing your core values. Grand Rapids, MI: Baker Books.

Mann, R. D. 1959. A review of the relationships between personality and performance in small groups. Psychological Bulletin 56:241-70.

Marshall, J. C. 2008. Servant-leadership and service-learning: A model for teaching community engagement to undergraduate students. Dissertation, East Carolina University, Greenville, NC. AAT 3303342.

May, D. R., A. Chan, T. D. Hodges, and B. J. Avolio. 2003. Developing the moral component of authentic leadership. Organizational Dynamics 32 (3): 247-60.

Mayer, D. M., M. Bardes, and R. F. Piccolo. 2008. Do servantleaders help satisfy follower needs? An organizational justice perspective. European Journal of Work and Organizational Psychology 17 (2): 180-97.

Mayer, R. C., J. H. Davis, and F. D. Schoorman. 1995. An integrative model of organizational trust. Academy of Management Review 20:709-34.

McCabe, D. L., K. D. Butterfield, and L. K. Treviño. 2001. Cheating in academic institutions: A decade of research. Ethics and Behavior 11 (3): 219-32.

McCabe, D. L., K. D. Butterfield, and L. K. Treviño. 2006. Academic dishonesty in graduate business programs: Prevalence, causes, and proposed action. Academy of Management Learning \& Education 5 (3): 294-305.

McClellan, J. L. 2007. A correlational analysis of the relationship between psychological hardiness and servant leadership among leaders in higher education. Dissertation, Gonzaga University, Spokane, WA. AAT 3302245.

Moore, B. V. 1927. The May conference on leadership. Personnel Journal 69 (1): 122-35.

Nebel, E. C., and G. K. Sterns. 1977. Leadership in the hospitality industry. Cornell Hotel and Restaurant Administration Quarterly 18 (3): 69-76.

Novicevic, M. M., W. Davis, F. Dorn, M. R. Buckley, and J. Brown. 2005. Barnard on conflicts of responsibility: Implications for today's perspectives on transformational and authentic leadership. Management Decision 43 (10): 1396-1409.

Nyham, R. C., and H. A. Marlowe. 1997. Development and psychometric properties of the organizational trust inventory. Evaluation Review 21 (5): 614-35.

Parolini, J., K. Patterson, and B. Winston. 2009. Distinguishing between transformational and servant leadership. Leadership \& Organization Development Journal 30 (3): 274-91.

Patterson, K. A. 2003. Servant leadership: A theoretical model. Dissertation, Regent University, Virginia Beach, VA. AAT 3082719

Reinke, S. J. 2004. Service before self: Towards a theory of servant-leadership. Global Virtue Ethics Review 5 (3): 30-57.

Rennaker, M.A. 2008. Listening and persuasion: Examining the communicative patters of servant leadership. Dissertation, Regent University, Virginia Beach, VA. AAT 3309285.

Rost, J. 1995. Leadership: A discussion about ethics. Business Ethics Quarterly 5 (1): 129-42.

Russell, R. F. 2001. The role of values in servant leadership. Leadership \& Organization Development Journal 22 (2): 76-84. 
Russell, R. F., and A. G. Stone. 2002. A review of servant leadership attributes: Developing a practical model. Leadership \& Organization Development Journal 23 (3/4): 145-57.

Sankowsky, D. 1995. The charismatic leader as narcissist: Understanding the abuse of power. Organizational Dynamics 23 (4): 57-71.

Schueler, J. 2000. Customer service through leadership: The Disney way. Training \& Development 54 (10): 26-31.

Sendjaya, S., and J. C. Sarros. 2002. Servant leadership: Its ori gin, development, and application in organizations. Journal of Leadership \& Organizational Studies 9 (2): 57-64.

Sendjaya, S., J. C. Sarros, J. C. Santora. 2008. Defining and measuring servant leadership behaviour in organizations. Journal of Management Studies 45 (2): 402-24.

Senge, P. M. 1990. The fifth discipline: The art and practice of the learning organization. New York: Doubleday.

Sharma, S. 2000. Managerial interpretations and organizational context as predictors of corporate choice of environmental strategy. Academy of Management Journal 43 (2): 681-98.

Shockley-Zalabak, P., K. Ellis, and G. Winograd. 2000. Organizational trust: What it means, why it matters. Organization Development Journal 18 (4): 35-48.

Simons, T. 2002. Behavioral integrity: The perceived alignment between managers' words and deeds as a research focus. Organization Science 13 (1): 18-35

Simons, T. 2008. The integrity dividend: Leading by the power of your word. San Francisco: Jossey-Bass.

Smith, B. N., R. V. Montagno, and T. N. Kuzmenko. 2004 Transformational and servant leadership: Content and contextual comparisons. Journal of Leadership \& Organizational Studies 10 (4): 80-91.

Spears, L. 1996. Reflections on Robert K. Greenleaf and servant-leadership. Leadership \& Organization Development Journal 17 (7): 33-35.

Spears, L. C. 1998a. Character and servant leadership: Ten characteristics of effective, caring leaders. Indianapolis, IN: Spears Center for Servant Leadership.

Spears, L. C., ed. 1998b. Insights on leadership: Service, stewardship, spirit, and servant leadership. New York: John Wiley.

Spears, L. C. 2004. Practicing servant-leadership. Leader to Leader 34:7-11.

Stein, M. 2007. Oedipus Rex at Enron: Leadership, oedipal struggles, and organizational collapse. Human Relations 60 (9): 1387-1410

Sternberg, L. E. 1992. Empowerment: Trust vs. control. Cornell Hotel and Restaurant Administration Quarterly 33 (1): 68-72.
Stewart, W. 2005. Servant leadership, stewardship and Winnie the Pooh. Presented at Canadian Outcomes Research Institute Meeting, Burnaby, British Columbia, Canada, February.

Stogdill, R. M. 1948. Personal factors associated with leadership: A survey of the literature. Journal of Psychology 25:35-71.

Stone, A. G., R. F. Russell, and K. Patterson. 2004. Transformational versus servant leadership: A difference in leader focus. Leadership \& Organization Development Journal 25 (3/4): 349-61.

Thaler-Carter, R. E. 2000. Whither global leaders? HR Magazine 45 (5): 82-88.

Tichy, N. M., and D. O. Ulrich. 1984. The leadership challenge: A call for the transformational leader. Sloan Management Review 26:59-68.

Tracey, J. B., and T. R. Hinkin. 1994. Transformational leaders in the hospitality industry. Cornell Hotel and Restaurant Administration Quarterly 35 (2): 18-24.

Tracey, J. B., and T. R. Hinkin. 1998. Transformational leadership or effective managerial practices? Group and Organization Management 23 (3): 220-36.

Van Velsor, E., and E. Ascalon. 2008. The role and impact of leadership development in supporting ethical action in organizations. Journal of Management Development 27 (2): 187-95.

Walker, R. G. 1986. Wellsprings of managerial leadership. Cornell Hotel and Restaurant Administration Quarterly 27 (2): 14-16.

Washington, R. R., C. D. Sutton, and H. S. Field. 2006. Individual differences in servant leadership: The roles of values and personality. Leadership \& Organization Development Journal 27 (8): 700-716.

Webb, A. 2010, January. Reshaping business education in a new era: Blair Sheppard, dean of Duke University's Fuqua School of Business, discusses how the expectations of MBA students are changing - and why the traditional MBA education needs to change as well. McKinsey Quarterly. 1-6.

Wong, P. T. P., and D. Davey. 2007. Best practices in servant leadership. Presented at Servant Leadership Research Roundtable, School of Global Leadership \& Entrepreneurship, Regent University, Virginia Beach, VA.

Yammarino, F. J., W. D. Spangler, and B. Bass. 1993. Transformational leadership and performance: A longitudinal investigation. Leadership Quarterly 4 (1): 81-102.

Yeung, S. 2004. Hospitality ethics curriculum: An industry perspective. International Journal of Contemporary Hospitality Management 16 (4): 253-62.

Judi Brownell, Ph.D., is professor in organizational behavior and management communication and dean of students at the Cornell School of Hotel Administration (jlb18@cornell.edu). She expresses appreciation to Rebecca Daniel for her excellent administrative assistance on this article. 